\title{
Effects of herbivores and water quality on Sargassum distribution on the central Great Barrier Reef: cross-shelf transplants
}

\author{
Laurence J. McCook* \\ Australian Institute of Marine Science \& CRC: Reef Research, Cape Ferguson, PMB No. 3, Townsville MC, Queensland 4810, \\ Australia
}

\begin{abstract}
On the central Great Barrier Reef, there is a marked gradient in abundance of macroalgae across the continental shelf. Fleshy brown macroalgae such as Sargassum are abundant on nearshore reefs and virtually absent from mid-shelf reefs. This gradient correlates with differences in abundance of herbivorous fish and with differences in water quality. lnshore fringing reefs have fewer and less diverse herbivorous fish and higher inputs of terrestrial nutrients and sediments. This study used a combination of cross-shelf transplants and herbivore exclusion cages to test the importance of water quality and herbivores to the survival of adult Sargassum. Sargassum survived and even thrived for up to $2 \mathrm{mo}$ on a mid-shelf reef, but only if protected from herbivores. Tissue nutrient analyses indicated that mid-shelf transplants were not limited by nitrogen or phosphorus supplies. Thus Sargassum can survive in the nutrient and sediment conditions on the mid-shelf reef. In this sense, the transplant serves as a partial test of water quality effects on Sargassum abundance. Herbivore exclusion was critical to survival of transplanted Sargassum on the mid-shelf reef but had no effect on survival in the nearshore fringing reef zone in which Sargassum normally occurs. There was significant spatial variation in survival of Sargassum, especially in the presence of herbivores.
\end{abstract}

KEY WORDS: Great Barrier Reef - Macroalgal distribution Sargassum Herbivore exclusion - Water quality Nutrients Transplant

\section{INTRODUCTION}

The abundance of algae on coral reefs is an important aspect of the ecological, environmental, aesthetic and socio-economic value of the reefs. Algal-dominated reefs may have lower fish stocks, tourism appeal and biodiversity. There is widespread concern that coral reefs are in global decline because of anthropogenic changes in water quality or fish stocks (e.g. Brown 1987, Hatcher et al. 1989, Done 1992a, Wilkinson 1993). Over-fishing or increases in nutrients and sediments in terrestrial runoff may lead to decreased abundance of hard corals and a dramatic increase in abundance of algal turfs and macroalgae (e.g Smith et al. 1981, LaPointe 1989, Hay 1991, Baldwin 1992, Done 1992a, Bell \& Tomascik 1993, Hughes 1994). The current study tests the importance of

·E-mail: l.mccook@aims.gov.au water quality and herbivorous fish to a large-scale gradient in macroalgal abundance on the central Great Barrier Reef (GBR), since that gradient may be an indicator, or model, of reef degradation.

On the central GBR, there is concern that increased nutrient and sediment loads in terrestrial runoff (Pringle 1986. Moss et al. 1992), from pastoral, agricultural (sugar) and tourism industries, may be contributing to the degradation of reefs (Yellowlees 1991, Baldwin 1992, Brodie 1995). Within this region, there is a marked crossshelf gradient in the relative abundance of coral and algae, apparently correlated with cross-shelf differences in water quality and the abundance of herbivorous fishes (Wilkinson \& Cheshire 1988). In particular, fucalean macroalgae such as Sargassum and Cystoseira are seasonally extremely abundant on nearshore fringing reef zones, and virtually absent from mid-shelf and outer-shelf reefs (Done 1982, author's pers. obs.). 
Possible causes of this gradient in macroalgal abundance include water quality effects on coral-algal competition; and herbivore control of macroalgae on mid-shelf and outer-shelf reefs. In comparison to midshelf and outer-shelf reefs, the inshore fringing reefs generally have low coral diversity and abundance by area (Done 1982 but only for reef flats inshore cf. midshelf), low recruitment and high post-settlement mortality of corals (Sammarco 1991), high nutrient availability (Furnas 1991, Furnas et al. 1993), high sedimentation rates and turbidity (Wolanski \& Jones 1981, author's pers. obs.) and low diversity, density and grazing rates of herbivorous fishes (Williams 1982 , Williams \& Hatcher 1983, Russ 1984a, unpubl. data, Williams et al. 1986, Scott \& Russ 1987).

The abundance of algae on inshore reefs may have resulted from anthropogenic increases in nutrient and sediment loads (Bell 1991, 1992, Moss et al. 1992), effects which may also threaten offshore reefs (Kinsey 1991, Baldwin 1992). There is photographic evidence (D. Wachenfeld unpubl. data) that abundant hard corals on some inshore reef flats have been replaced by macroalgae over the last several decades. However, Sargassum has apparently been abundant on reef flats at Great Palm Island, central GBR, for more than 50 yr (D. Wachenfeld unpubl, data, E. Bunn pers. comm. cf. Doty 1954). Furnas et al. (1993) found crossshelf gradients in particulate nitrogen and phosphorus, which were higher inshore, presumably due to riverine input and resuspension. However, dissolved nutrients did not show clear cross-shelf gradients.

Evidence that increases in nutrients and sediments can lead to declines in coral abundance and increased macroalgal abundance comes particularly from studies of sewage effects on reefs (Smith et al. 1981, Maragos et al. 1985, Kinsey 1988, LaPointe \& O'Connell 1989). The mechanism of these shifts may involve either direct nutrient enhancement of algal growth (LaPointe et al. 1987, LaPointe \& O'Connell 1989), or negative effects on corals of nutrients or sediments (e.g. Tomas: cik \& Sander 1985, Morrissey 1988, Stafford-Smith 1992). These effects may also be indirect, since chronic nutrient or sediment stress may inhibit coral recovery after acute mortality events (Kinsey 1988).

There is considerable evidence from Caribbean reefs for the importance of herbivory to macroalgal distributions and the relative dominance of corals, turfs and macroalgae, but little work has been done on the GBR. On many reefs, high rates of herbivory maintain algal turfs with low biomass and high productivity (Hatcher \& Larkum 1983, Russ 1987, Carpenter 1988, 1990, Hatcher 1988, Steneck 1988, Klumpp \& McKinnon 1989, 1992, Klumpp \& Polunin 1990). Numerous studies using experimental transplants and/or herbivore exclusion (cages) have shown herbivory to affect the distribution or abundance of various algal groups at various scales, from damselfish territories (Hixon \& Brostoff 1981, 1983 in Hawail, Sammarco 1983 on GBR), zones or habitats within reefs (Hay 1981a, b, 1984a, b, 1985, Sammarco 1982a, Hay et al. 1983, Littler et al. 1983a, b. Hay \& Taylor 1985, Lewis 1985, 1986, Lewis \& Wainwright 1985, Carpenter 1986, Lewis et al. 1987, Morrison 1988, all on Caribbean reefs) to whole patch reefs (Sammarco 1982b). Mass mortalities of Diadema urchins on over-fished reefs in the Caribbean led to very large scale shifts from coral to algal dominance (Hughes et al, 1987, Hughes 1989, 1994, Carpenter 1990). On the GBR, several studies have found that algal recruitment and abundance increased in the absence of herbivorous fishes (Stephensen \& Searles 1960, Hatcher \& Larkum 1983, Williams et al. 1986, Scott \& Russ 1987, G. Russ unpubl. data). However, none of these studies examined possible causes of differences in macroalgae abundance across the continental shelf, or between habitats. Steinberg et al. (1991) found Sargassum to be grazed on mid-shelf reefs, but did not test its survival in the absence of herbivory, nor use return transplants

The relationships between water quality, herbivore abundance and benthic communities across the GBR are highly suggestive, but they have not been reliably quantified, scaled or causally tested (Wilkinson \& Cheshire 1988). This paper aims to provide a partial test of water quality and herbivory as causes for the cross-shelf differences in abundance of Sargassum, by testing the ability of mature Sargassum to survive on mid-shelf reefs, in the presence and absence of herbivorous fishes. Sargassum plants were transplanted from an inshore reef to a mid-shelf reef and their survival compared with that of plants returned to the inshore reef. Herbivore effects were tested by comparing survival of plants in cages with that of unprotected plants. Transplants alter the algae's environmental conditions, including water quality, and thereby provide a partial test for effects of any water quality parameter on Sargassum distribution. If the algae can survive on a mid-shelf reef, this would suggest that Sargassum is not directly limited by any environmental conditions on the mid-shelf, including nutrient or sediment availability.

\section{METHODS}

Experimental design. To test for differences in Sargassum viability across the continental shelf, adult Sargassum plants were transplanted $40 \mathrm{~km}$ from an inshore fringing reef (Goold Island) to several sites on a mid-shelf platform reef (Otter Reef) or returned to sites on Goold Island (Figs. 1 \& 2). At each reef, the 


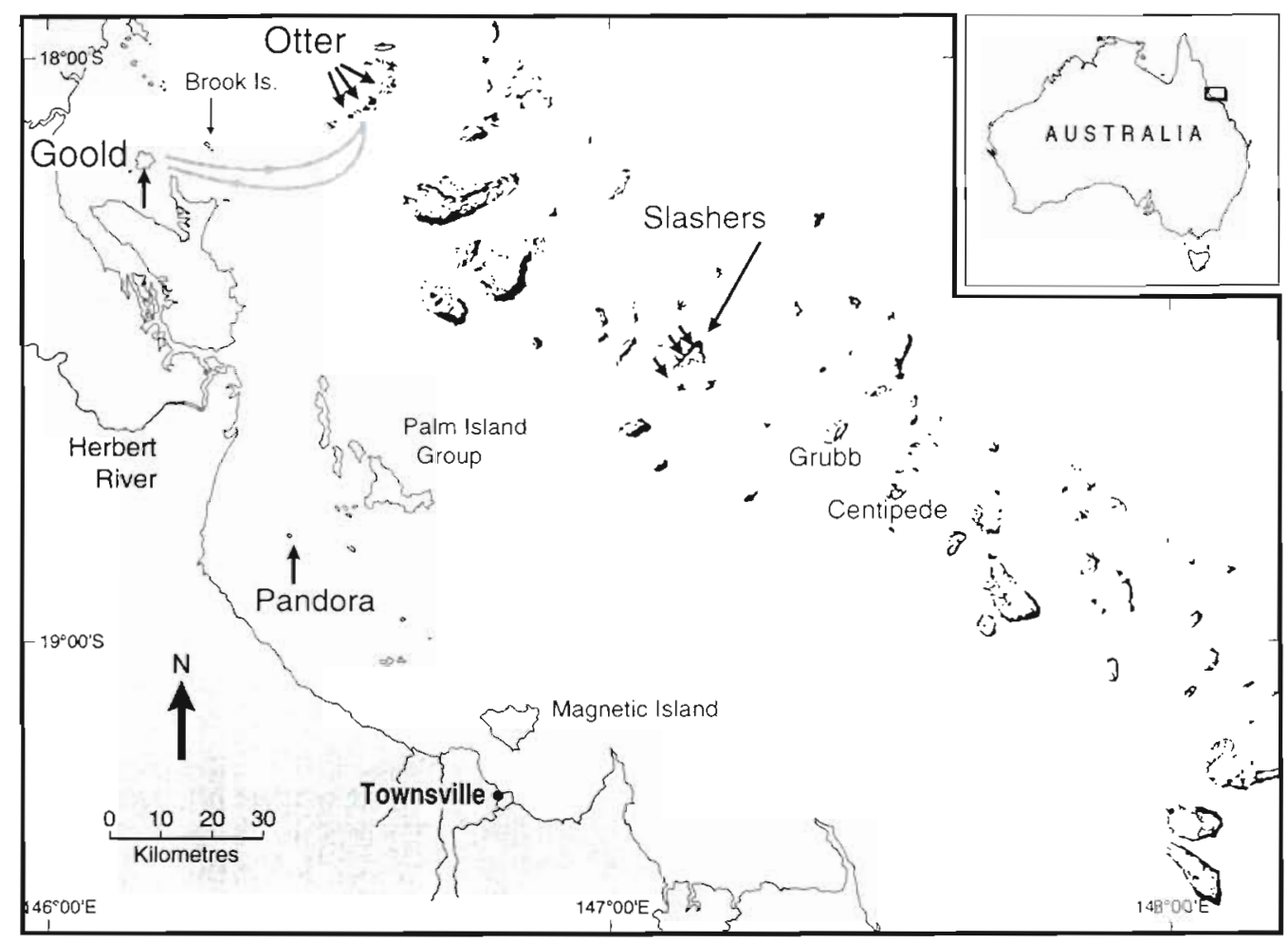

Fig. 1. Townsville area and central Great Barrier Reef showing study sites. Sargassum and many other macroalgae are generally more abundant on the fringing reefs of nearshore continental islands (grey) than on the mid-shelf and outer-shelf reefs (black). These inshore fringing reefs are generally exposed to higher sediment and nutrient input from terrestrial runoff and have lower abundance and diversity of herbivorous fishes, as discussed in text. The importance of these factors to Sargassum survival was tested by transplanting Sargassum from fringing reefs (Goold and Pandora) to mid-shelf reefs (Otter and Slashers) and comparing survival to plants returned to the reef of origin. Only the northern reef pair (Goold-Otter) are analysed since most of the plots in the southern pair were lost due to very strong winds. Plots were distributed amongst 3 sites spread out on each reef. Preliminary studies transplanted Sargassum from Magnetic and Brook Islands to Grubb and Centipede Reefs

plants were (1) exposed to ambient levels of herbivory in open, uncaged plots; (2) protected with large mesh cages (1 cage per plot); or (3) placed in partial cages (to control for cage artifacts). The experimental design was a nested factorial combination of shelf zone [2 levels: inshore (Goold Island) and mid-shelf (Otter Reef)] and herbivore exclusions ( 3 levels: open, uncaged plots; caged plots; and partial-cage controls). Nested within each combination of shelf zone and cage treatment were 4 replicate plots (or cages), each with 6 replicate plants. Replicate plots were spread out across the reefs, to test for spatial variation in treatment effects. Finally, to compare survival of undisturbed plants with transplants on the inshore reef, some plants were tagged and left undisturbed at Goold Island.

The design analysed is a simplification of a larger experiment which was partly lost to bad weather. The original design included 2 pairs of inshore and midshelf reefs (Fig. 1), 3 sites nested within each reef, and 3 plots nested within each site. Sites within reefs were between $500 \mathrm{~m}$ and $5 \mathrm{~km}$ apart, and plots were several metres apart, to test for spatial variation in effects at these 2 scales. Unfortunately, exceptionally windy conditions resulted in the loss of most plots in the southern pair of reefs (Pandora and Slashers Reefs; Fig 1), and many of those at Otter Reef (particularly cages). Consequently, the analysis had to be simplified to combine sites and plots, and only used 1 reef pair Data were randomly discarded to achieve a balanced design with 4 plots in each treatment combination. The interpretive consequences are (1) that effects of shelf zone cannot be distinguished from reef-specific differences between Goold Island and Otter Reef; and (2) that the nested factor (plots) includes spatial variation at scales of metres to $5 \mathrm{~km}$. Still, these scales can be distinguished at Goold Island, where no plots were lost and both sites and plots could be analysed. The possibility of reef-specific (or year-specific) effects is also partially avoided by comparison with preliminary studies on different reefs (from Brook and Magnetic Islands to Grub and Centipede Reefs; Fig 1), a year earlier

The transplantation lasted nearly 2 mo during the summer period of maximum abundance of this species 


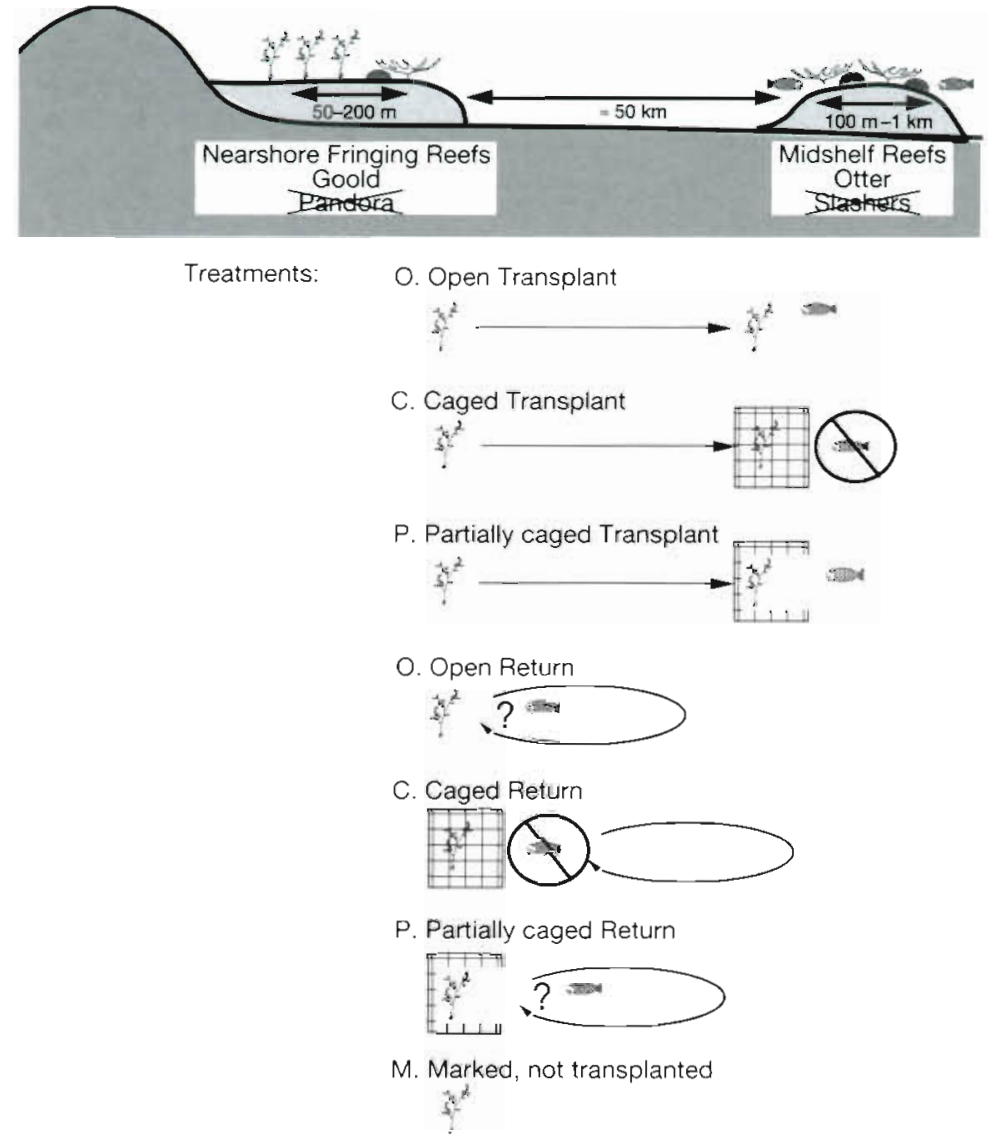

Fig. 2. Diagram of cross-shelf differences in reefs and experimental treatments. Sargassum plants were transplanted from an inshore fringing reef to a mid-shelf reef where Sargassum does not normally occur. Transplant artifacts were tested with return transplants to the inshore reef, and with plants which were tagged and left undisturbed. Herbivore effects were tested using large mesh cages. Scales are only approximate. Data from the southern reef pair (Pandora and Slashers) were lost due to bad weather

(December 1993 and January 1994). Large and healthy Sargassum siliquosum plants were collected from the reef flat on the southern side of Goold Island $\left(18^{\circ} 11^{\prime} \mathrm{S}\right.$, $146^{\circ} 10^{\prime} \mathrm{E}$ ), by cutting the holdfast as close to the attachment as possible. Twenty randomly selected plants were not collected but tagged with flagging tape and left in place. Collected plants were randomised and the holdfast inserted between the strands of $4 \mathrm{~mm}$ polypropylene rope. Six plants were placed approximately 100 to $200 \mathrm{~mm}$ apart on each rope and were maintained in running seawater in $1000 \mathrm{I}$ polypropylene tanks (Reln Plastics, Townsville) throughout the transplantation. All plants were transported to Otter Reef $\left(18^{\circ} 03^{\prime} \mathrm{E}, 146^{\circ} 34^{\prime} \mathrm{E}\right)$ and randomly selected ropes placed on plots at Otter Reef 1 to $1.5 \mathrm{~d}$ after collection. Remaining plants were returned to Goold Island and randomly placed 2 to $3 \mathrm{~d}$ after collection. The Goold Island transplants were in worse condition when placed than those at Otter Reef, due to very rough conditions on the return journey. Plants were retrieved after $7 w \mathrm{k}$, and counted (density of fronds per plant, in 4 size classes: $0-5,5-15$, $15-50$ and $50+\mathrm{cm}$ ), then dried and weighed. It was not possible to remove epiphytes before weighing because the Sargassum tissue was generally too necrotic and soft on heavily fouled plants. Unfortunately extremely poor visibility meant that only 3 of 20 untransplanted tagged plants could be relocated.

Open (uncaged) plots were marked with 4 steel fence (star) pickets. Cages, $0.75 \mathrm{~m}$ high by $0.75 \times 0.75 \mathrm{~m}$, were made of $12 \mathrm{~mm}$ plastic mesh (Nylex, 'Trical' high density polyethylene), with an $8 \mathrm{~mm}$ steel rod frame, anchored with steel fence (star) pickets and plastic cable ties. Partial cages were identical to cages except that 1 or 2 large holes (approx. $40 \times$ $40 \mathrm{~cm}^{2}$ ) were cut in each side to allow access for swimming herbivores.

To test for water quality effects on plant tissue nutrients, 3 randomly selected dried plants from each caged plot were analysed for effects of transplantation on tissue carbon, nitrogen and phosphorus. These analyses used caged plants only, to exclude herbivore effects. Thus the experimental design was a 1 -factor (reef) nested ANOVA. Tissue carbon and nitrogen were analysed by high temperature combustion and gas chromatography using a Perkin Elmer CHNS 2400 elemental analyser. Tissue phosphorus was determined on a Varian liberty 220 plasma emission spectrometer, following perchloric/nitric acid digestion.

Study reefs. The fringing reef at Coold Island is exposed to considerable terrigenous sediment and nutrient inputs from the Herbert River and extensive mangroves of Hinchinbrook Island and Channel (central GBR) (Wolanski et al. 1990, G. Brunskill unpubl. data). The reef faces south, and is approximately $500 \mathrm{~m}$ wide, with extensive beds of Sargassum on the reef edge and slope. The reef slope drops off to very soft terrigenous muds at about $6 \mathrm{~m}$. Sargassum was collected on the outer reef flat ( tidal datum), but return transplants were placed within Sargassum beds at similar depth but further inshore (to allow the use of pickets to anchor cages and plants).

Otter Reef is a large, crescent-shaped, mid-shelf platform reef, with extensive areas of shallow coralline or sandy reef flat. Transplants were placed in reef flat areas as subjectively similar to the inshore reef flat as possible: i.e. shallow, relatively flat and open, and generally sandy to allow anchoring of cage structures. These sites were about 0.5 to $1 \mathrm{~m}$ below tidal 
datum, with nearby coral bommies. Since the physical structure of inshore and mid-shelf reefs is very different, these areas were chosen to minimise biases (type I error), as they are the areas least likely to be affected by herbivorous fishes (Russ 1984b), and generally have the greatest abundance of other fleshy macroalgae. Thus if herbivory is important in these areas, it is probably generally important on these reefs.

Data analyses. Data were analysed for effects on dry weight (biomass), total density of fronds per plant, size distribution and C:N and C:P ratios. Untransplanted, tagged plants were not included in statistical analyses since they were not part of the main factorial design, and only 3 were relocated. Treatment effects on size distributions were compared graphically and as quantitative comparisons of the estimated mean frond length for each plant, estimated as (estimated total frond length for plant)/(total frond number for plant). Estimated total frond length was calculated as $\sum\left(\mathrm{n}_{\text {szze class }} \times\right.$ length $\left.\mathrm{h}_{\text {size class }}\right)$ where $\mathrm{n}_{\text {size class }}$ is the number of fronds in a size class; and length size class is the midpoint of each size class: $2.5,10,32.5$ and $60 \mathrm{~cm}$ respectively $(60 \mathrm{~cm}$ was chosen subjectively for the largest class).

Systat ${ }^{\mathrm{TM}} 5.02$ was used for ANOVAs, with cage treatments and reefs as fixed factors, plots nested within reefs and cage treatments, and using the nested factor mean square as the denominator for the $F$-tests. Since dry weight, density and mean length gave significant interactions between reef (shelf zone) and caging treatments, these were then analysed for reef effects within treatments and treatment effects within reefs, using Ryan's Q-test (Day \& Quinn 1989). Within reef and treatment analyses were also analysed using nested ANOVAs (cf. Ryan's test), to test for spatial effects within treatments or reefs (analyses not tabulated). As indicated above, within Goold Island data were also analysed for site effects, as a 2 -factor nested ANOVA, using all available data 3 sites and 3 treatments, 3 plots nested in sites and treatments, 6 plants per plot, analysis not shown). Similarly, reef effects within open plots could also be analysed with more data ( 8 plots nested within each reef) since more open plots survived than cages (analyses not shown). Where the $\mathrm{p}$-value for the nested factor (plot) was $>0.25$, data were reanalysed pooling the nested factor and residuals (Table 2, both analyses shown in Underwood 1981). Magnitudes of effects were estimated by the percentage of total variability attributed to factors (\% SST). All data were tested for homogeneity of variances (Cochran's $C$-test), independence and normality of residuals (graphically). Dry weight was square root transformed, as indicated by the relationship between residuals and estimates.

\section{RESUITS}

The results of this study show that Sargassum was viable on the mid-shelf reefs where it is not normally found, but only if protected from herbivores. Qualitative observations clearly showed that Sargassum plants in cages from the mid-shelf reef were healthy, vigorous, had abundant distal photosynthetic tissues (leaves, vesicles and distal stipes) and had few epiphytes. In contrast, plants exposed to herbivores were reduced to basal stipes with few or no distal fronds, were heavily fouled with epiphytes and were necrotic. Plants returned to the inshore fringing reef were not as healthy as those from mid-shelf reef cages, or those left in place on the fringing reef. However, they did retain many leaves, vesicles and smaller fronds and were not heavily fouled or necrotic. On this reef, there were no obvious differences between plants kept in cages and plants exposed to any herbivores

In general these observations were borne out by the quantitative analyses as: significant interactions between reef and cage treatment; significantly lower biomass, density and mean frond length of unprotected compared to caged plants on the mid-shelf reef; and no significant effects of caging on the nearshore fringing reef. Caging artifacts appeared to be minimal, since partial cage treatments were never significantly different from open plots, despite some fouling of cage mesh. Graphical comparisons of untransplanted tagged plants indicated that Goold Island return transplants suffered more transplantation damage than those left at Otter Reef. Tissue nutrient analyses did not show any indications of nutrient limitation on the mid-shelf reef.

\section{Effects on biomass (dry weight)}

The dry weight of Sargassum tissue remaining after 2 mo transplantation showed large differences in the effects of caging treatments on the 2 reefs (and vice versa; Fig. 3, Table 1; significant reef $x$ treatment interaction). Comparisons within reefs showed that at Goold Island there was no significant effect of herbivores and that caging treatment accounted for very little variability (Fig. 3. Table 1; 1\% SST using nested ANOVA within Goold Island, details not shown). Variation between plants accounted for most variation at Goold Island. Although there was nearly a significant difference amongst sites when looking at all the available data (2-factor nested ANOVA; see 'Methods'), this accounted for very little variability $(4 \%$ SST).

In contrast, on the mid-shelf at Otter Reef, herbivore exclusion appears very important (Fig. 3, Table 1). Caging treatments were highly significant and 

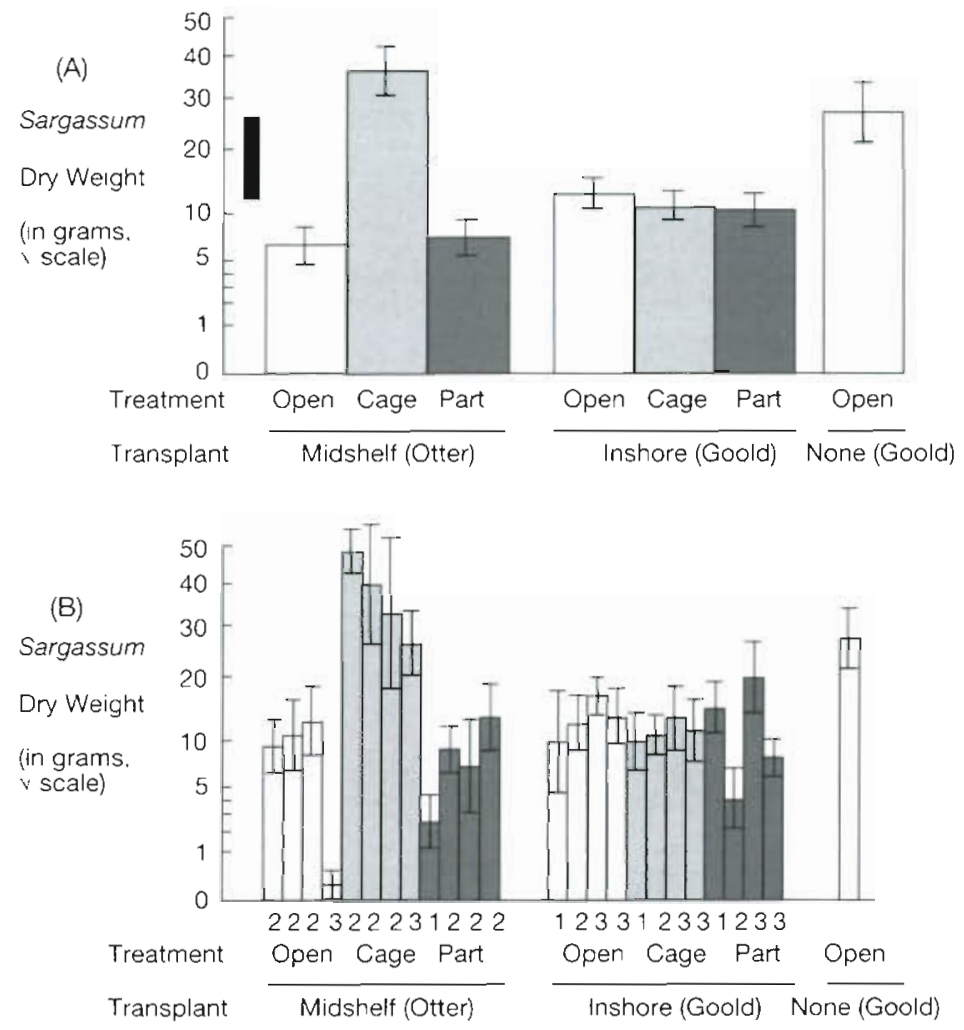

Fig. 3. Effects of transplantation and herbivory on biomass of Sargassum. Dry weight of tissue after 2 mo. Data are scaled to $\sqrt{d r y}$ weight (A) Data averaged over all 4 plots at each reef and treatment combination, i.e. mean ( \pm SE) of 24 replicates, ignoring nested factor (plots). Solid bar indicates the critical value for significant difference between 2 means, using Ryan's test. (B) Means $( \pm$ SE) of 6 replicates for each plot, arranged as for (A). Numbers underneath bars indicate in which of 3 sites at each reef the plot was located. Data for untransplanted Sargassum at Goold ('None') are the mean $( \pm \mathrm{SE})$ of 3 replicates for both (A) \& (B) accounted for much of the variation (39\% SST for nested ANOVA within Otter Reef, details not shown). There was nearly significant variability between plots in the same treatments (Fig 3B; nested ANOVA within Otter Reef; $p=0.059,14 \%$ SST). It is not strictly possible to determine the scale of spatial variability (plots versus sites in the original design). However, Fig $3 \mathrm{~B}$ suggests that plants exposed to herbivores varied more between than within sites (i.e. scale of kilometres), whereas variation in cages was largely within sites.

Comparisons between reefs within treatments (Fig 3A, Table 1) give the surprising result that remaining biomass on the nearshore reef was similar to that in open or partially caged plants on the midshelf reef and less than that in the caged treatments. Two observations suggest this result should be interpreted carefully (see 'Discussion'). First, there was considerable epiphyte biomass on uncaged midshelf transplants that was not present on inshore plants. Secondly, the biomass remaining on untransplanted plants was apparently similar to that of caged plants on Otter Reef and higher than that of most Goold Island transplants (Fig. 3; no statistical test). This suggests that the low biomasses at Goold Island resulted mainly from the losses during return transplantation and not from poor growth/survival inshore.

Table 1 Analyses of transplant and herbivore effects on Sargassum biomass. Data are transformed to dry weight Treatment refers to the cage treatments in all tables. Since there was a significant interaction between cage treatments and reefs, Ryan's $Q$ test was used for multiple comparisons of treatment effects within reefs, and reef effects within treatments. Underlines indicate differences not significant. Ryan's test used the mean square (MS) of plot factor with $\mathrm{df}=18, \mathrm{n}=24$, number of means $\mathrm{m}=6$, and rank = 3 or 2 (Day \& Quinn 1989). The \% of total variation (sum of squares) explained by each factor is indicated by \% SST. Homogeneity of variance tests are shown as Cochran's $C$-statistic $C_{c r t}$ is the critical value for $C$

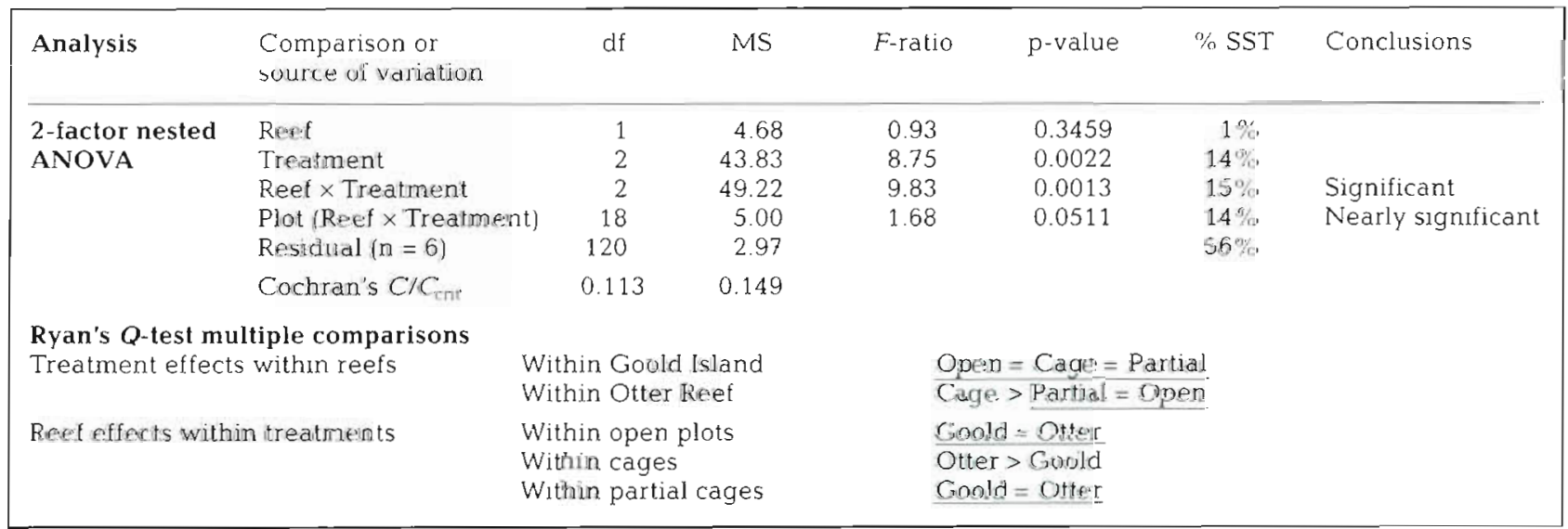




\section{Effects on total frond density}

The effects on the total density of Sargassum fronds remaining after 2 mo transplantation were similar to those on biomass: large differences in effects of caging treatments on the 2 reefs (and vice versa; Fig. 4, Table 2 ; significant reef $x$ treatment interaction). However, thore was generally more residual variation between plant densities than observed for biomass. Within Goold Island there was again no significant effect of herbivores, caging treatment accounted for very little variability, spatial variation was insignificant and most variation was between plants (Fig. 4, Table 2; 2-factor nested ANOVA within Goold Island shows that treatment, site, and plot were all not significant; 1 and $95 \%$ SST for treatment and residual respectively; see 'Methods').

At Otter Reef, Sargassum density was higher in herbivore exclusions (Fig. 4, Table 2 ), although background variation between plants was high $(-70 \%$ SST from nested ANOVA within Otter Reef). Spatial variation was not significant ( $p>0.3,12 \%$ SST), although Fig 4B suggests a difference amongst open plants at different sites.

Comparisons of densities between reefs within treatments (Fig. 4A, Table 2) were inconclusive, since differences were not significant for open or caged plants. Again, this result should be interpreted carefully, and in the light of densities within size classes (see below and 'Discussion'). As with biomass, the density of untransplanted plants was apparently similar to that of caged plants at Otter Reef (Fig. 4; no statistical test).

\section{Effects on size distribution}

Comparisons of frond size distributions in different groups resolve some of the effects on density. Effects of treatments on frond length distributions varied between reefs and vice versa (Fig. 5, Table 3; significant reef $x$ treatment interaction). Within Goold Island, frond size distribution was generally similar between treatments (Fig. 5, Table 3) although there were small but significant differences in mean frond length between sites (spatial scale of hundreds of metres; $\mathrm{p}<0.05,4 \%$ SST, analyses not shown). Interestingly, the size distributions of transplants were not subjectively very different to that of untransplanted tagged plants (although generally less in each size class).

In contrast, at Otter Reef, there were substantially fewer fronds in the largest size class in plants exposed to herbivores (Fig. 5, Table 3; treatments accounted for $50 \%$ of $\%$ SST in mean frond length; $p \approx 0.001$, details not shown). Comparisons of mean frond length within treatments were nearly significant (for nested ANOVA within Otter Reef; p and \% SST: 0.081, 23\%; 0.052, $13 \%$; and $0.068,16 \%$ for open, caged and partially caged respectively). Combined with comparisons of size distributions within treatments (Fig. 5), this suggests that distributions at Goold Island were intermediate between those of caged and uncaged plants on Otter Reef, particularly in abundance of large $(>50 \mathrm{~cm})$ fronds.

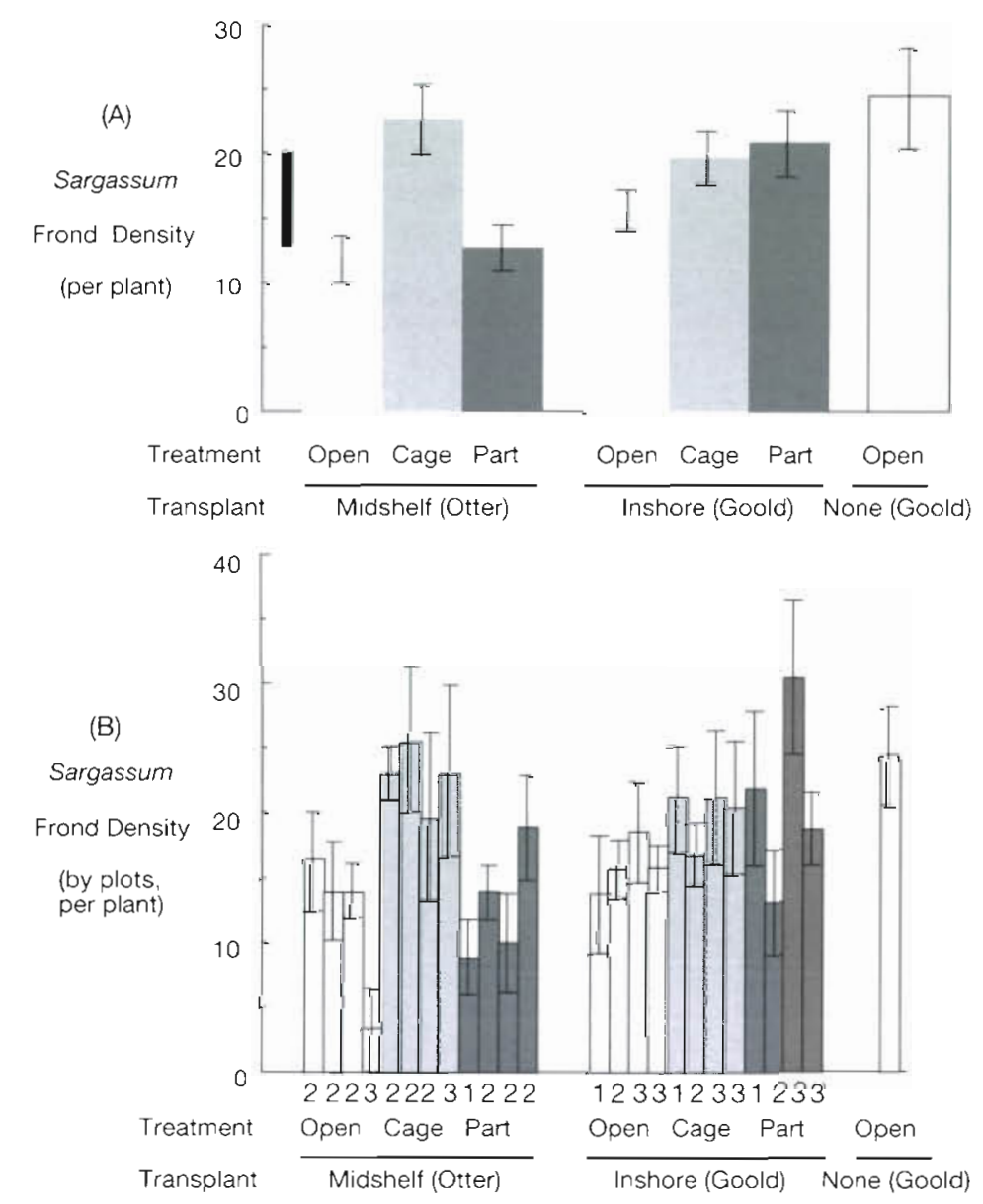

Fig. 4. Effects of transplantation and herbivory on total frond density of Sargassum. Density as numbers of fronds per plant after 2 mo, calculated as the sum of all 4 size classes in Fig. 5. (A) Data averaged over all 4 plots at each reef and treatment combination, i.e. mean ( \pm SE) of 24 replicates, ignoring nested factor (plots). Solid bar indicates the critical value for significant difference between 2 means, using Ryan's test. (B) Means ( \pm SE) of 6 replicates for each plot, arranged as for (A). Numbers underneath bars indicate in which of 3 sites at each reef the plot was located. Data for untransplanted Sargassum at Goold ('None') are the mean ( \pm SE) of 3 replicates for both $(A) \&(B)$ 
Table 2. Analyses of transplant and herbivore effects on Sargassum density. Data are total numbers of all 4 size classes of fronds per plant. Other abbreviations as in Table 1. Since the nested factor Plot was highly non-significant, p[Plot(Reef $\times$ Treatment)] $>0.25$, Residual and Plot terms were pooled. Results for the nested analysis are shown in italics. Since there was a significant interaction between cage treatments and reefs, Ryan's Q-test was used for multiple comparisons of treatment effects within reefs, and reef effects within treatments. Underlines indicate differences not significant. Ryan's test used the mean square (MS) of pooled residual with $\mathrm{df}=138, \mathrm{n}=24$, number of means $\mathrm{m}=6$, and rank $=3$ or 2 (1)ay \& Quinn 1989)

\begin{tabular}{|c|c|c|c|c|c|c|c|}
\hline Analysis & $\begin{array}{l}\text { Comparison or } \\
\text { source of variation }\end{array}$ & df & MS & F-ratio & $p$-value & SST & Conclusions \\
\hline 2-iactor nested & Reeef & 1 & 330.03 & 3.027 & 0.0841 & $2 \%$ & \\
\hline \multirow{7}{*}{ ANOVA } & Treatment & 2 & 687.02 & 6.300 & 0.0024 & $8 \%$ & \\
\hline & Reef $\times$ Treatment & 2 & 379.09 & 3.477 & 0.0336 & $4 \%$ & Significant \\
\hline & Plot (Reef $\times$ Treatment) & 18 & 122.11 & 1.140 & 0.3227 & $13 \%$ & Not significant \\
\hline & Residual $(n=6)$ & 120 & 107.07 & & & $73 \%$ & \\
\hline & Pooled Residual $(\mathrm{n}=24)$ & 138 & 109.03 & & & $86 \%$ & \\
\hline & \multirow{2}{*}{$\begin{array}{l}\text { Cochran's } C / C_{c n t} \\
\text { Cochran's } C \text { pooled }\end{array}$} & 0.100 & 0.149 & & & & \\
\hline & & 0.220 & 0.267 & & & & \\
\hline \multicolumn{8}{|c|}{ Ryan's $Q$-test multiple comparisons } \\
\hline \multirow{2}{*}{\multicolumn{2}{|c|}{ Treatment effects within reefs }} & \multirow{2}{*}{\multicolumn{2}{|c|}{$\begin{array}{l}\text { Within Goold Island } \\
\text { Within Otter Reef }\end{array}$}} & \multirow{2}{*}{\multicolumn{3}{|c|}{$\frac{\text { Partial }=\text { Cage }=\text { Open }}{\text { Cage }>\text { Partial }=\text { Open }}$}} & \\
\hline & & & & & & & \\
\hline \multirow{3}{*}{\multicolumn{2}{|c|}{ Reef effects within treatments }} & \multirow{3}{*}{\multicolumn{2}{|c|}{$\begin{array}{l}\text { Within open plots } \\
\text { Within cages } \\
\text { Within partial cages }\end{array}$}} & \multirow{3}{*}{\multicolumn{3}{|c|}{$\begin{array}{l}\text { Goold }=\text { Otter } \\
\text { Otter } \approx \text { Goold } \\
\text { Goold }>\text { Otter }\end{array}$}} & \\
\hline & & & & & & & \\
\hline & & & & & & & \\
\hline
\end{tabular}

\section{Tissue nutrient analyses}

Tissue nutrient analyses indicate that mid-shelf Sargassum transplants were not limited by nitrogen or phosphorus supplies. There was no significant effect of

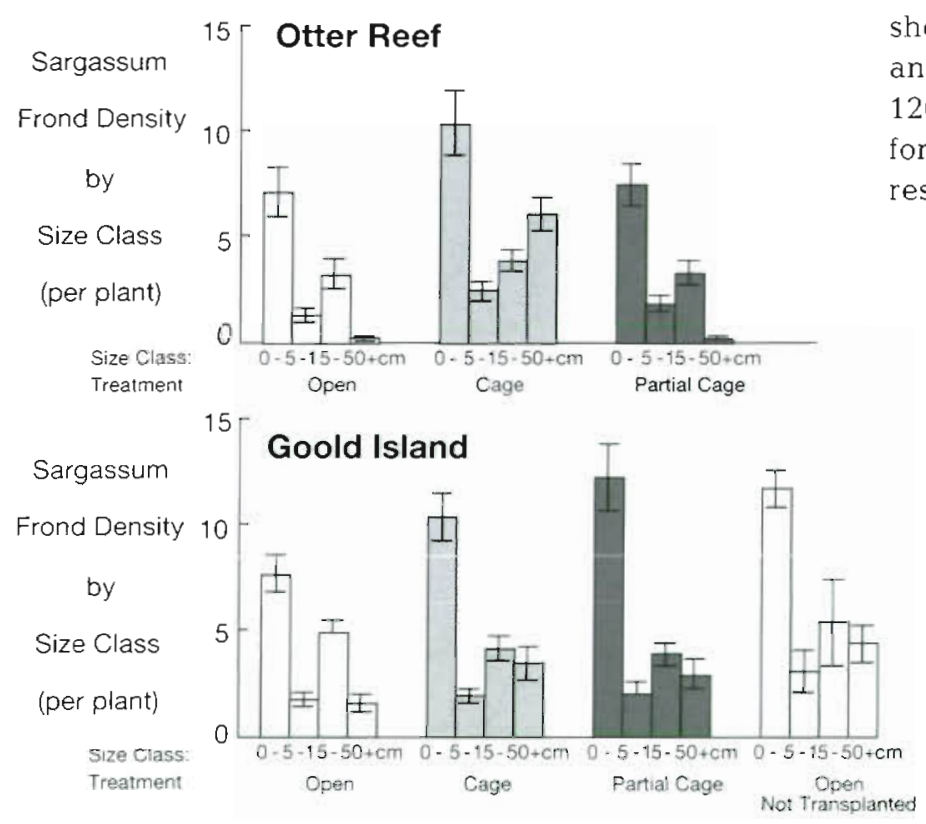

Fig. 5. Effects of transplantation and herbivory on size distribution of Sargassum fronds. Size distribution after 2 mo. Data, numbers of fronds per plant, are averaged over all 4 plots at each reef and treatment combination, i.e. mean ( \pm SE) of 24 replicate plants, ignoring nested factor (plots). Data for untransplanted Sargassum at Goold ('Not Transplanted') are the mean ( \pm SE) of 3 replicates reef on either tissue $\mathrm{C}: \mathrm{P}$ ratios or tissue phosphorus amounts by weight $(\mathrm{p}=0.92,0.64 ; \% \mathrm{SST}=<1 \%,<5 \%$ respectively). Surprisingly, tissue nitrogen was significantly higher in plants transplanted to Otter Reef (by weight or $\mathrm{C}: \mathrm{N}$ ratio), which is difficult to explain but certainly precludes nitrogen limitation on the midshelf reef $(p=0.02,0.006 ; \%$ SST $=34 \%, 52 \%$ for $\mathrm{C}: \mathrm{N}$ and by weight respectively). Mean C:N:P ratios were 1261:39.4:1 for Otter Reef transplants and 1278:32.8:1 for Goold Island (standard deviations for C:P, N:P respectively: $194,8.9$ for Otter; $271,8.2$ for Goold).

\section{Results from other reeis}

Although most plots on the southern pair of reefs were lost (see 'Methods'), some open and partially caged plants were found on the mid-shelf reef. These were similar to the analogous plants on Otter Reef, implying that the patterns at Otier Reef were general. Preliminary transplants to Grubb and Centipede Reefs a year earlier also largely supported the above results. Biomass was higher for plants protected from herbivores than unprotected plants (means $\pm \mathrm{SEM}=16.6 \pm$ $6.74 \mathrm{~g}$ and $5.68 \pm 4.39 \mathrm{~g}, \mathrm{n}=4,8$ for caged and uncaged plants respectively; ANOVA on rank transformed data, $p=0.04$ ). In these cases, there was considerable spatial variability in herbivory on mid-shelf reefs over distances of hundreds of metres. This spatial variability outweighed any differences between years and reefs. 
Table 3. Analyses of transplant and herbivore effects on size distribution of Sargassum. Data are estimated mean length of frond for each plant, calculated as the (number in each size class) x (approx. length of that size class) / (total density of all size classes) (see 'Data analysis'). Other abbreviations as in Table 1 Since there was a significant interaction between cage treatments and reefs, Ryan's Q-test was used for multiple comparisons of treatment effects within reefs, and reef effects within treatments. Underlines indicate differences not significant. Ryan's test used the mean square (MS) of plot factor with $\mathrm{df}=18, \mathrm{n}=24, \mathrm{number}$ of means $m=6$, and rank $=3$ or 2 (Day \& Quinn 1989)

\begin{tabular}{|c|c|c|c|c|c|c|c|}
\hline Analysis & $\begin{array}{l}\text { Comparison or } \\
\text { source of variation }\end{array}$ & $\mathrm{df}$ & MS & F-ratio & p-value & $\%$ SST & Conclusions \\
\hline 2-factor nested & Reef & 1 & 187.80 & 2.071 & 0.1673 & $2 \%$ & \\
\hline \multirow{5}{*}{ ANOVA } & Treatment & 2 & 1060.12 & 11.690 & 0.0006 & $22 \%$ & \\
\hline & Reef $\times$ Treatment & 2 & 565.230 & 6.233 & 0.0088 & $12 \%$ & Highly significant \\
\hline & Plot(Reef $\times$ Treatment) & 18 & 90.69 & 2.332 & 0.0035 & $17 \%$ & Highly significant \\
\hline & Residual $(n=6)$ & 120 & 38.88 & & & $48 \%$ & \\
\hline & Cochran's $C / C_{\text {crit }}$ & 0.106 & 0.149 & & & & \\
\hline \multicolumn{2}{|c|}{ Treatment effects within reefs } & \multicolumn{2}{|c|}{$\begin{array}{l}\text { Within Goold lsland } \\
\text { Within Otter Reef }\end{array}$} & \multicolumn{3}{|c|}{$\begin{array}{l}\text { Cage }=\text { Open }=\text { Partial } \\
\text { Cage }>\text { Partial = Open }\end{array}$} & \\
\hline \multicolumn{2}{|c|}{ Reef effects within treatments } & \multicolumn{2}{|c|}{$\begin{array}{l}\text { Within open plots } \\
\text { Within cages } \\
\text { Within partial cages }\end{array}$} & \multicolumn{3}{|c|}{$\begin{array}{l}\text { Goold }>\text { Otter } \\
\text { Otter } \approx \text { Goold } \\
\text { Goold } \approx \text { Otter }\end{array}$} & \\
\hline
\end{tabular}

\section{DISCUSSION}

These results show that transplanted adult Sargassum siliquosum were viable on mid-shelf reefs for several months, but only if protected from herbivores Survival varied between plants, and at scales of metres, kilometres, and probably at between-reef scales. While these conclusions may prove specific to particular circumstances, they do suggest that the cross-shelf difference in abundance of Sargassum is not due to any direct effect of water quality on Sargassum, but due to its exclusion by the more abundant herbivorous fish on offshore reefs. While there is considerable previous evidence for herbivore effects on algal zonation within reefs (see 'Introduction'), this is apparently the first experimental demonstration of herbivory contributing to a geographic gradient in macroalgal abundance (but see Williams et al. 1986).

Sargassum held in mid-shelf water conditions (in cages) for a period of 2 mo not only survived at least as well as inshore plants, but had no sign of depressed tissue nutrient levels. This is strong evidence that the plants are not excluded from mid-shelf reefs by nutrient limitations, at this stage and scale. Tissue C:N:P ratios for both mid-shelf and inshore transplants were low in $\mathrm{P}$ but similar in $\mathrm{N}$ compared to the very few published data (Atkinson \& Smith 1983). B. Schaffelke (unpubl. data) has found that these algae show rapid $(<10$ d) declines in tissue nutrient stores in response to limiting nutrient conditions in the laboratory. Given that mid-shelf caged plants thrived and sustained their tissue nutrient levels for $2 \mathrm{mo}$, nutrient limitation seems unlikely over longer periods. Similarly, J. Umar et al. (unpubl. data) have found that another species of fringing reef Sargassum is inhibited by fine sediments, so that low levels of terrestrial sediments on mid-shelf reefs are unlikely to directly limit Sargassum.

\section{Interpretation and context of results}

Four related factors affect the detailed interpretation and context of this experiment: (1) cages as herbivorous fish exclusions; (2) the low biomass of return transplants, relative to mid-shelf transplants or non-transplants; (3) data losses and spatial variation; and (4) the specificity, generality and context of the results. While the results are highly indicative of the relative importance of herbivory and water quality to cross-shelf differences in algal abundance, they neither prove nor disprove the importance of these factors, nor preclude the importance of other factors. The study demonstrates that $12 \mathrm{~mm}$ mesh cages preclude some critical factor on mid-shelf reefs, but does not prove that this factor is herbivorous fish. Herbivorous fish are the most reasonable explanation, since the results for partial cages and the higher mortality of longer fronds are both consistent with grazing by swimming herbivores. The heavy epiphyte load and poor condition of plants on open midshelf plots suggest that loss of photosynthetic tissues to grazing may leave the remaining tissue with insufficient resources for growth or defense against epiphytes. Steinberg et al. (1991) also found Sargassum to be grazed by fish on mid-shelf reefs in this area, although apparently more rapidly than the current study.

Secondly, the low biomass of inshore plants is mostly a transplant artifact, rather than a cross-shelf effect. 
Sargassum biomass in open and caged plots on the nearshore reef was similar to those of mid-shelf open plots and substantially less than that in caged mid-shelf plots. However, the inshore plants were initially much lower in biomass, due to the rough return trip (see 'Methods'). Further, the heavy fouling of open midshelf plants means that dry weights overestimate Sargassum biomass. Inshore plants were fairly healthy and clean, and still had healthy, distal, photosynthetic tissues. Comparisons of size-class distributions indicate similar proportions of classes for all inshore treatments, including the untransplanted plants (Fig. 5). In contrast the open mid-shelf plants had very few longer fronds. This evidence all implies that different processes were affecting inshore and uncaged. mid-shelf plants (presumably rough transplant and herbivory respectively).

However, it is possible that Sargassum also grows better in mid-shelf cages than on the inshore reef, growth that is offset by herbivory in the open plots. The size distribution data suggest that caged mid-shelf plants had proportionally more long fronds than any other group (Fig. 5), including untransplanted plants. The available data certainly imply that (caged) midshelf conditions are at least as suitable as inshore conditions. Note that while the transplant artifact on inshore plants compromises the interpretation of crossshelf differences, it is not critical to the main purpose of the design. By distinguishing between effects of transplant stress and the new environment, the return transplants control for the possibility that all (midshelf) transplants die due to transplant stress. Since some mid-shelf transplants thrived at least as well as the untransplanted plants, transplants to mid-shelf reefs are clearly valid.

Thirdly, growth and survival varied at spatial scales from kilometres to metres and between plants. This variability appeared largest amongst mid-shelf plants exposed to herbivores, and thus probably reflects patchiness in grazing intensity. As detailed in 'Methods', the loss of the southern reef pair and the merging of nested levels (plots and sites) involves some loss of spatial resolution. However, comparisons with the preliminary experiments and the few plants recovered from the southern reefs support the general conclusions of a spatially variable but real effect of herbivores on mid-shelf reefs. Figs. 3B \& 4B suggest that this effect varies at scales of both metres and kilometres.

Fourthly, the context of these (variable) results is quite specific: 1 species of Sargassum, 1 pair of reefs, 1 season, a relatively short period, adult plants, and a particular zone on the mid-shelf reef. The abundance of both corals and algae would probably be influenced by many process and interactions, including direct and indirect competition for space and light; absolute and relative effects of water quality on recruitment, growth and reproduction of both groups; and different rates of consumption by herbivores (including corallivores) Each of these processes and their effects is likely to depend on predictable or stochastic variations in scale. circumstances and history and to vary depending on the species or groups concerned (e.g. Hay 1984a, 1991, Hughes et al. 1987, Hughes 1989; also Foster 1990, McCook \& Chapman 1991, 1993 for temperate examples; McCook 1994). The variability and complexity of the system mean that the results of individual experiments should not be extrapolated to other circumstances without considerable caution.

Nonetheless, the results of preliminary studies and other work do suggest that the results are not specific to the particular season, zone, reefs, year, species or stage, but represent a genuine cross-shelf pattern, albeit with considerable variation between reefs. Although Sargassum is highly seasonal in this area, similar transplants within fringing reefs suggest that herbivore effects do not depend on season (author's unpubl. data). Since the mid-shelf transplants were placed on reef flat zones that I considered most analogous to the Sargassum zone of inshore reefs (areas with relatively low densities of herbivores), it seems unlikely that Sargassum would survive in other zones on mid-shelf reefs. Thus, unprotected Sargassum may be generally unable to survive herbivory on these reefs. Since Steinberg et al. (1991) found several species of Sargassum to be heavily grazed, there seems no a priori reason to assume species-specific effects. While this study did not consider the survival of juvenile plants, unprotected Sargassum recruits would presumably be grazed at least as severely as the adults. Fucalean juveniles are generally more vulnerable to herbivory than the adults (e.g. Lubchenco 1983), and on mid-shelf reefs, recruits would be indistinguishable from the (heavily grazed) turfs. Hence herbivory is probably important to all stages of Sargassum.

\section{Causes of cross-shelf distribution of Sargassum}

Thus, the cross-shelf difference in herbivory, and not water quality, appears to be a direct cause of the crossshelf differences in Sargassum. However, this explanation should be seen in the context of: (1) interactions with corals and other benthos; (2) the possible dispersal of Sargassum propagules, given the cross-shelf geography; and (3) the similar differences in abundance of Sargassum over very small distances between zones within fringing reefs.

Critically, other effects of mid-shelf water quality on Sargassum remain possible, independent of herbivore effects. It is possible that water quality limits recruitment, or has indirect effects on algae by affecting coral 
competitors or herbivores. For example, if coral cover is reduced under conditions of high nutrients and/or sediments, then space available for Sargassum colonisation would be greater. Similarly, herbivore abundance may be influenced by water quality, or by availability of shelter amongst corals

Poor dispersal may contribute to the low abundance of Sargassum on mid-shelf reefs in the short-term, although it is insufficient as a long-term explanation. Sargassum colonisation of mid-shelf reefs is likely to be rare, since dispersal of fucalean algal spores generally is restricted to within a few metres from parent plants (Deysher \& Norton 1982, Kendrick \& Walker 1991). Sargassum recruitment is apparently extremely low even on the inshore reefs (author's unpubl. data) and cross-shelf transport would be unusual, since currents are predominantly longshore (but not exclusively; Pickard et al. 1977).

However, at longer time scales, there would seem ample opportunity for colonisation, if Sargassum populations could persist on mid-shelf reefs. I have found an isolated individual of Sargassum sp. on an outer shelf reef in this area (Faraday Reef, $18^{\circ} 26^{\prime} \mathrm{S}, 147^{\circ} 21^{\prime} \mathrm{E}$, author's unpubl. surveys), and further north, in the Cooktown area, Sargassum can be found in isolated patches on mid-shelf reef flats and as rare individuals at the base of reef slopes (Price et al. 1976, author's pers. obs.). Detached but healthy Sargassum plants are known to drift long distances, and can occasionally be seen in mid-shelf areas (author's pers. obs., I. R. Price pers. comm.). Assuming that some of these plants are fertile, they would provide a mechanism for Sargassum colonisation, at least on historical time scales

Thus Sargassum appears able to disperse to midshelf reefs but not able to establish populations. Herbivore effects therefore are relevant to the long-term absence of Sargassum on these reefs (cf. Underwood \& Denley 1984): herbivory appears to prevent the establishment of Sargassum populations on the rare occasions when plants successfully recruit to mid-shelf reefs. Presumably the clear-cut difference in Sargassum abundance in this area reflects the wide separation of inshore and mid-shelf reefs and consequently low ratio of Sargassum colonisation to grazing rates.

Cross-shelf differences in herbivore impact on Sargassum must also be placed in the context of similar differences and effects over very small distances between zones on fringing reefs. The abundance of Sargassum varies as dramatically between zones on fringing reefs as it does across the shelf, and I have found similar apparent herbivore effects, using similar transplants and cages to the current study (author's unpubl. data). This suggests that similar processes may be contributing to both within-fringing reef and cross-shelf differences. Although Sargassum recruit- ment is apparently low throughout these inshore reefs (author's unpubl. data), poor dispersal is unlikely to explain the long-term absence of Sargassum in zones less than $100 \mathrm{~m}$ from Sargassum beds.

Within-reef zonation of both algae and herbivorous fishes varies across the continental shelf. The extent of within-reef zonation in Sargassum varies between inshore fringing reefs in the Townsville area (author's pers obs.). Further north, the presence or abundance of Sargassum on reef flats declines gradually toward the mid-shelf (author's pers obs.). The relatively low abundance of herbivorous fish on nearshore reefs (Williams 1982, Williams \& Hatcher 1983, Russ 1984a, Williams et al. 1986) was measured in coral zones, but fish abundance appears lower still in Sargassum zones (author's pers. obs.), perhaps due to the lack of shelter provided by corais. On mid-shelf reefs, herbivores are also less abundant on reef flat areas than reef front zones (Russ 1984b).

Integrating the patterns between and within reefs suggests that the long-term establishment of a Sargassum zone may depend on the ratio of recruitment to herbivory, and the temporal and spatial scale of those processes. According to this view, mid-shelf reef flats in the Townsville area would have rare recruitment overwhelmed by moderate herbivory. There are probably small refuges from herbivory but poor propagule supply would prevent any colonists from establishing populations. Further north, occasional sparse Sargassum beds occur on mid-shelf reef flats, where moderately low herbivory is insufficient to control more frequent Sargassum recruitment. This would be scale dependent, since an extensive reef flat would provide greater refuge from herbivores based on the reef front. Inshore, the coral zone of fringing reefs would be subject to higher recruitment levels, but higher grazing intensity prevents colonisation. Inshore fringing reef flats would have abundant Sargassum beds because recruitment is sufficient and herbivory is minimal.

This balance between Sargassum dispersal and herbivory would also depend on other factors. For example, abundance of corals may influence both availability of substrate for Sargassum colonisation and herbivore abundance. Herbivorous fish apparently prefer the topographically complex, coral-dominated reef fronts to reef flats (Randall 1965. Talbot et al. 1978 , Russ 1984a, author's pers. obs.). Thus, the impact of both recruitment and herbivory would depend on initial dominance by macroalgae or corals (e.g. Hughes 1989), in turn reflecting disturbance history (Hughes et al. 1987, Hughes 1989, 1994, Done 1992b) and even nutrient or sediment stress (Kinsey 1988)

In summary, the results of this study indicate that cross-shelf differences in Sargassum abundance can be partially explained by differences in herbivory, but 
not by direct effects of water quality on adult plants Water quality may still affect Sargassum through direct effects on juveniles, or indirect effects on competitors (e.g. corals, other algae) or herbivores. Thus, while Sargassum adults do not depend on high levels of water nutrients or sediments, their presence may still be an indicator of water quality. Sargassum survival varies considerably within zones, between zones within reefs (author's unpubl. data) and across the shelf. Cross-shelf patterns in algal abundance may reflect qualitatively similar processes to small-scale patterns within fringing reefs.

Acknowledgements. I am grateful for the support of the Australian Institute of Marine Science, of D. Klumpp, T. Done and A. Robertson, and of the Cooperative Research Centre for Ecologically Sustainable Development of the Great Barrier Reef. The experience, advice, skill and good company of the masters and crew of the RV 'Sirius', RV 'Hercules' and RV 'Messel', and in particular of P. Eden, J. Shurp and D. Smallwood, are greatly appreciated. I thank R. Burns, G. B. Croft (yet again), T. Foyle, C. Humphries, J. Hyne, D. McKinnon, M. O'Rourke, D. Smallwood, and J. Wity for diving and field assistance and $\mathrm{N}$. Taylor for laboratory assistance. I thank also A. Hatcher, B. Hatcher and C. Johnson for the discussions that initiated this work; $K$. Edyvane for valuable suggestions and for essential clarification of Sargassum taxonomy and identification; and T. Done, G. Inglis, J. Skeat and several reviewers for comments on the manuscript. This is AIMS Publication No. 792

\section{LITERATURE CITED}

Atkinson MJ, Smith SV (1983) C:N:P ratios of benthic marme plants. Limnol Oceanogr 28:568-574

Baldwin CL (1992) Impact of elevated nutrients in the Great Barrier Reef. GBRMPA Research Publication No. 20 , Townsville

Bell PRF (1991) Status of eutrophication in the (ireat Barrier Reef lagoon. Mar Pollut Bull 23:89-93

Bell PRF (1992) Eutrophication and coral reefs - some examples in the Great Barrier Reef lagoon. Water Res 26: $553-568$

Bell PRF, Tomascik T (1993) The demise of the fringing coral reefs of Barbados and regions in the Great Barrier Reef (GBR) lagoon - impacts of eutrophication. In: Proceedings on Global Aspects of Coral Reefs, Health. Hazards and History, June 10-11. University of Miami, Miami, FL, p P1-P15

Brodie J (1995) The problem of nutrients and eutrophication in the Australian marine environment. In: Zann L. Sutton $D$ (eds) The state of the marine environment report for Australia. Technical Annex 2. Dept of Environment. Sport and Territories, Canberra, ACT, p 1-29

Brown BE (1.987) World wide death of corals: natural cyclic events or man-made pollution? Mar Pollut Bull 18:9-13

Carpenter RC (1986) Partitioning herbivory and its effects on coral reef algal communitıes. Ecol Monogr 54:345-363

Carpenter RC (1988) Mass mortality of a Caribbean sea urchin: immediate effects on community metabolism and other herbivores. Proc Nath Acad Sci USA 85:511-514

Carpenter RC (1990) Mass mortality of Diadema antillarum. I. Long term effects on sea urchin population dynamics and coral reef algal communitıes. Mar Bıol 104:67-77
Day RW, Quinn GP (1989) Comparisons of treatments after an analysis of variance in ecology. Ecol Monogr 59:433-463

Deysher L, Norton TA (1982) Dispersal and colonization in Sargassum muticum (Yencio) Fenshdt. J Mar Biol Ass UK $56: 179-195$

Done TJ (1982) Patterns in the distribution of coral communities across the central Great Barrier Reef. Coral Reefs 1: 95-107

Done T (1992a) Phase shifts in coral reef communities and their ecological significance. Hydrobiologia 247:121-132

Done T (1992b) Constancy and change in some Great Barrier Reef coral communities: 1980-1990. Am Zool 32:655-662

Doty MS (1954) Distribution of the algal genera Rhipilia and Sargassum in the central Pacific. Pacif Sci 8:367-368

Foster MS (1990) Organization of macroalgal assemblages in the Northeast Pacific: the assumption of homogeneity and the illusion of generality. Hydrobiologia 192:21-33

Furnas MJ (1991) The nutrient status of Great Barrier Reef waters. In: Yellowlees D (ed) Land use patterns and nutrient loading of the Great Barrier Reef region. Sir George Fisher Centre for Tropical Marine Studies, James Cook University of North Queensland, Townsville, p 162-179

Furnas MJ, Mitchell AW, Skuza M (1993) Nitrogen and phosphorus budgets for the central Great Barrier Reef shelf. GBRMPA, Townsville

Hatcher BG (1988) Coral reef primary productivity: a beggar's banquet. TREE 3:106-111

Hatcher BG, Johannes RE, Robertson Al (1989) Review of research relevant to the conservation of shallow water tropıcal marine ecosystems. Oceanogr Mar Biol A. Rev 27 : $337-414$

Hatcher BG, Larkum AWD (1983) An experimental analysis of factors controlling the standing crop of the epilithic algal community on a coral reef. J Exp Mar Biol Ecol 69:61-84

Hay ME (1981a) Herbivory, algal distribution, and the maintenance of between-habitat diversity on a tropical fringing reef. Am Nat 118:520-540

Hay ME (1981b) Spatial patterns of grazing intensity on a Caribbean barrier reef: herbivory and algal distribution. Aquat Bot 11:97-1.09

Hay ME (1984a) Patterns of fish and urchin grazing on Caribbean coral reefs: are previous results typical? Ecology 65:446-454

Hay ME (1984b) Predictable spatial escapes from herbivory how do these affect the evolution of herbivore resistance in tropical marine communities? Oecologia 64:396-407

Hay ME (1985) Spatial patterns of herbivore impact and their importance in maintaining algal species richness. Proc 5th Int Coral Reef Congr. Tahit 4:29-34

Hay ME (1991) Fish-seaweed interactions on coral reefs effects of herbivorous fishes and adaptations of their prey. In: Sale PF (ed) The ecology of fishes on coral reefs. Academic Press, San Diego, p 96-119

Hay ME, Colburn T, Downing D (1983) Spatial and temporal patterns in herbivory on a Caribbean fringing reef: the effects on plant distribution. Oecologia 58:299-308

Hay ME, Taylor PR (1985) Competition between herbivorous fishes and urchins on Caribbean reefs. Oecologia 65: 591-598

Hixon MA, Brostoff WN (1981) Fish grazing and community structure of Hawailan reef algae. Proc 4 th Int Symp Coral Reefs, Manila 2:507-514

Hixon MA, Brostoff WN (1983) Damselfish as keystone species in reverse: intermediate disturbance and diversity of reef algae. Science 220:511 -513

Hughes TP (1989) Communty structure and diversity of coral reefs: the role of history. Ecology 70:275-279 
Hughes TP (1994) Catastrophes, phase-shifts and large scale degradation of a Caribbean coral reef. Science 265: $1547-1551$

Hughes TP, Reed DC, Boyle M (1987) Herbivory on coral reefs: community structure following mass mortalities of sea urchins. J Exp Mar Biol Ecol 113:39-59

Kendrick GA, Walker DI (1991) Dispersal distances for propagules of Sargassum spinuligerum (Sargassaceae, Phaeophyta) measured directly by vital staining and venturi suction sampling. Mar Ecol Prog Ser 79:133-138

Kinsey DW (1988) Responses of coral reef systems to elevated nutrents. In: Baldwin CL (ed) Nutrients in the Great Barrier Reef region. Workshop Series No. 10. GBRMPA, Townsville, p 55-65

Kinsey DW (1991) Water quality and its effect on reef ecology. In: Yellowlees D (ed) Land use patterns and nutrient loading of the Great Barrier Reef region. Sir George Fisher Centre for Tropical Marine Studies, James Cook University of North Queensland, Townsville, p 192-196

Klumpp DW, McKinnon A (1989) Temporal and spatial patterns in primary production of a coral-reef epilithic algal community. J Exp Mar Biol Ecol 131:1-22

Klumpp DW, McKinnon A (1992) Community structure, biomass and productivity of epilithic algal communities on the Great Barrier Reef: dynamics at different spatial scales. Mar Ecol Prog Ser 86:77-89

Klumpp DW, Polunin NVC (1990) Algal production, grazers and habitat partitioning on a coral reef: positive correlation between grazing rate and food availability. In: Barnes M, Gibson RN (eds) Trophic relationships in the marine environment: Proc 24th Europ Mar Biol Symp. Aberdeen University Press, Aberdeen, p 372-388

Lapointe BE (1989) Caribbean coral reefs: are they becoming algal reefs? Sea Front 35:84-91

Lapointe BE, Littler MM, Littler DS (1987) A comparison of nutrient-limited productivity in macroalgae from a Caribbean barrier reef and from a mangrove ecosystem. Aquat Bot 28:243-255

Lapointe BE, O'Connell J (1989) Nutrient-enhanced growth of Cladophora prolifera in Harrington Sound, Bermuda: eutrophication of a confined, phosphorus-limited marine ecosystem. Estuar Coast Shelf Sci 28:347-360

Lewis SM (1985) Herbivory on coral reefs: algal susceptibility to herbivorous fishes. Oecologia 65:370-375

Lewis SM (1986) The role of herbivorous fishes in the organization of a Caribbean reef community. Ecol Monogr 56: $183-200$

Lewis SM, Norris JN, Searles RB (1987) The regulation of morphological plasticity in tropical reef algae by herbivory. Ecology 68:636-641

Lewis SM, Wainwright PC (1985) Herbivore abundance and grazing intensity on a Caribbean coral reef. J Exp Mar Biol Ecol 87:215-228

Littler MM, Littler DS, Taylor PR (1983a) Evolutionary strategies in a tropical barrier reef system: functional-form groups of marine macroalgae. J Phycol 19:229-237

Littler MM. Taylor PR, Littler DS (1983b) Algal resistance to herbivory on a Caribbean barrier reef. Coral Reefs 2: $111-118$

Lubchenco J (1983) Littorina and Fucus: effects of herbivores, substratum heterogeneity, and plant escapes during succession. Ecology 64:1116-1123

Maragos JE, Evans C, Holthus P (1985) Reef corals in Kaneohe Bay six years before and after termination of sewage discharges. Proc 5th Int Coral Reef Congr, Tahiti $4: 189-194$
McCook LJ (1994) Understanding ecological community succession: causal models and theories, a review. Vegetatio 110:115-147

McCook LJ, Chapman ARO (1991) Community succession following massive ice-scour on an exposed rocky shore: effects of Fucus canopy algae and of mussels during late succession. J Exp Mar Biol Ecol 154:137-169

McCook LJ, Chapman ARO (1993) Community succession following massive ice-scour on a rocky intertidal shore: recruitment, competition and predation during early, primary succession. Mar Biol 115:565-575

Morrison D (1988) Comparing fish and urchin grazing in shallow and deeper coral reef algal communities. Ecology 69: $1367-1382$

Morrissey J (1988) Nutrient history of the Great Barrier Reef aquarium. ln: Baldwin CL (ed) Nutrents in the Great Barrier Reef region. Workshop Series No. 10. GBRMPA, Townsville, p 92-96

Moss AJ, Rayment GE, Reilly N, Best EK (1992) Sediment and nutrient exports from Queensland coastal catchments, a desk study. Dept Environment \& Heritage and Dept Primary Industry, Brisbane, Queensland

Pickard GL, Donguy JR, Henin C, Rougerie F (1977) A review of the physical oceanography of the Great Barrier Reef and Western Coral Sea. Australian Institute of Marine Science Monograph Series 2, Aust Gov Publ. Service, Canberra

Price IR, Larkum AWD, Bailey A (1976) Appendix: check list of marine benthic plants collected in the Lizard Island area. Aust J Plant Physiol 3:3-8

Pringle AW (1986) Causes and effects of changes in fluvial sediment yield to the north-east Queensland coast, Australia. James Cook University of North Queensland Geography Dept Monograph Series, Occasional Paper 4

Randall JE (1965) Grazing effect on seagrasses by herbrvorous reef fishes in the West Indies. Ecology 46:255-260

Russ GR (1984aj Distribution and abundance of herbivorous fishes in the central Great Barrier Reef. I. Levels of variability across the entire continental shelf. Mar Ecol Prog Ser 20:23-34

Russ GR (1984b) Distribution and abundance of herbivorous fishes in the central Great Barrier Reef. Il. Patterns of zonation of mid-shelf and outershelf reefs. Mar Ecol Prog Ser $20: 35-44$

Russ GR (1987) Is rate of removal of algae by grazers reduced inside territories of tropical damselfishes? J Exp Mar Biol Ecol 110:1-17

Sammarco PW (1982a) Effects of grazing by Diadema antillarum philippi (Echinodermata: Echinoidea) on algal diversity and community structure. J Exp Mar Biol Ecol 65:83-105

Sammarco PW (1982b) Echinoid grazıng as a structuring force in coral communities: whole reef manipulations. J Exp Mar Biol Ecol 61:31-55

Sammarco PW (1983) Effects of fish grazing and damselfish territoriality on coral reef algae. l. Algal community structure. Mar Ecol Prog Ser 13:1-14

Sammarco PW (1991) Geographically specifıc recruitment and postsettlement mortality as influences on coral communities: the cross-continental shelf transplant experiment. Limnol Oceanogr 36:496-514

Scott FJ, Russ GR (1987) Effects of grazing on species composition of the epilithic algal community on coral reefs of the central Great Barrier Reef. Mar Ecol Prog Ser 39:293-304

Smith SV, Kimmener WJ, Laws EA, Brock RE, Walsh TW (1981) Kaneohe Bay sewage diversion experiment: perspectives on ecosystem responses to nutritional perturbation. Pacif Sci 35:279-395 
Stafford-Smith MG (1992) Mortality of the hard coral Leptoria phrygla under persistent sediment influx. Proc 7 th Int Symp Coral Reefs 1:289-299

Steinberg PD, Edyvare K, de Nys R, Birdsey R, van Altena IA (1991) Lack of avoidance of phenolic-rich brown algae by tropical herbivorous fishes. Mar Biol 109: $335-343$

Steneck RS (1988) Herbivory on coral reefs: a synthesis. Proc 6th Int Symp Coral Reefs 1:37-49

Stephensen W. Searles RB (1960) Experimental studies on the ecology of intertidal environments at Heron Island. Aust J Mar Freshwat Res 11:241-267

Talbot FH, Russel BC, Anderson GRV (1978) Coral reef fish communities: unstable high-diversity systems? Ecol Monogr 48:425-440

Tomascik T, Sander F (1985) Effects of eutrophication on reef building corals: growth rate of the reef building coral Montastrea annularis. Mar Biol 87:143-155

Underwood AJ (1.981) Techniques of analysis of variance in experimental marine biology and ecology. Oceanogr Mar Biol A Rev 19:513-605

Underwood AJ, Denley EJ (1984) Paradigms, explanations and generalizations in models for the structure of intertidal communities on rocky shores. In: Strong DR Jr. Simberloff D, Abele LG, Thistle AB (eds) Ecological communities: conceptual issues and the evidence. Princeton University Press, Princeton, NJ, p 151-180

This article was presented by D. M. Alongi (Senior Editorial Advisor), Townsville, Australia
Wilkinson CR (1993) Coral reefs of the world are facing widespread devastation: can we prevent this through sustainable management practices? Proc 7 th Int Symp Coral Reefs Guam 1:11-21

Wilkinson CR, Cheshire AC (1988) Cross-shelf variations in coral reef structure and function-influences of land and ocean. Proc 6th Int Symp Coral Reefs 1:227-233

Williams DMc:B (1982) Patterns in the distribution of fish communities across the central Great Barrier Reef. Coral Reefs $1: 35-43$

Williams DMcB, Hatcher AI (1983) Structure of fish communities on outer slopes of inshore, mid-shelf and outer shelf reefs of the Great Barrier Reef. Mar Ecol Prog Ser 10 $239=250$

Williams DMcB, Russ G, Doherty PJ (1986) Reef fish: largescale distribution and recruitment. Oceanus 29:76-82

Wolanski 1.. Jones M (1981) Physical properties of Great Barrier Reef lagoon waters near Townsville. I. Fffects of Burdekun River floods. Aust J Mar Freshwat Res 22:305-319

Wolanski E, Yoshihiro M, King B, (iay S (1990) Dynamics, flushing and trapping in Hinchinbrook Channel, a glant mangrove swamp. Australia. Estuar Coast Shelf Sci 31 $555-579$

Yellowlees D (1991) Land use patterns and nutrient loading of the Great Barrier Reef region. Sir George Fisher Centre for Tropical Marine Studies, James Cook University of North Queensland, Townsville

Manuscript first received: January 24, 1995

Revised version accepted: February 26, 1996 